\title{
IMPLEMENTASI MODEL PEMBELAJARAN IPS BERBASIS KEARIFAN LOKAL DI SMP NUSANTARA MAKASSAR
}

\author{
Oleh: \\ HASNI ${ }^{1}$, MUH. SAID ${ }^{2}$ \\ ${ }^{1,2}$ Fakultas Ilmu Sosial, Universitas Negeri Makassar \\ ${ }^{1}$ E-mail: hasni@unm.ac.id \\ ${ }^{2}$ E-mail: muh.said@unm.ac.id
}

\begin{abstract}
ABSTRAK: Salah satu hal yang diharapkan dapat mengembangkan potensi diri peserta didik dalam proses belajar mengajar adalah penggunaan model-model pembelajaran yang dipadupandankan dalam metode mengajar. Hal ini, dikarenakan masalah yang dihadapi dunia pendidikan kita adalah rendahnya proses pembelajaran dengan penggunaan model pembelajaran. Penggunaan model pembelajaran pada mata pelajaran IPS dituntut agar peserta didik lebih kreatif dan mampu mengembangakan model pembelajaran. Maka dari itu salah satu pendekatan yang paling tepat adalah pembelajaran yang berbasis kearifan lokal. Tujuan dalam penelitian ini adalah untuk mengetahui implementasi model pembelajaran IPS berbasis kearifal lokal di SMP Nusantara Makassar. Adapun jenis digunakan dalam penelitan ini yakni penelitian kualitatif karena data yang dikumpulkan bukan berupa angka melainkan data tersebut berasal dari observasi, wawancara dan dokumentasi. Penelitian ini termasuk penelitian kualitatif deskrptif yang cenderung menggunakan analisis dengan pola nalar induktif. Hasil penelitian dapat diketahui bahwa implementasi model pembelajaran IPS berbasis kearifan lokal di SMP Nusantara Makassar adalah guru IPS menggunakan dua model pembalajaran IPS berbaisis kearifan lokal yaitu model pembelajaran mind mapping dan model pembelajaran discovery learning.
\end{abstract}

Kata kunci: Model Pembelajaran, Mata Pelajaran IPS, Kearifan Lokal, Sekolah Menengah Pertama (SMP)

ABSTRACT: One of the things that is expected to develop students' self potential in the teaching and learning process is the use of learning models that are coupled in the teaching method. This is because the problem facing our education world is the low learning process by using learning models. The use of learning models in social studies subjects is required so that students are more creative and able to develop learning models. Therefore one of the most appropriate approaches is learning based on local wisdom. The purpose of this study was to determine the implementation of social wisdom learning models based on local wisdom in Makassar Nusantara Middle School. The type used in this research is qualitative research because the data collected is not in the form of numbers but the data comes from observations, interviews and documentation. This study includes descriptive qualitative research that tends to use analysis with inductive reasoning patterns. The results of the study can be seen that the implementation of social science learning models based on local wisdom in Makassar Nusantara Junior High School is a social studies teacher using two social studies learning models based on local wisdom, namely the mind mapping learning model and the discovery learning learning model.

Keywords: Learning Model, Social Studies Subjects, Local Wisdom, Junior High Schools (SMP) 


\section{PENDAHULUAN}

Mutu pendidikan sangat erat hubungannya dengan mutu peserta didik, karena peserta didik merupakan titik pusat proses belajar mengajar. Oleh sebab itu, dalam meningkatkan mutu pendidikan harus diikuti dengan mutu peserta didik. Peningkatan mutu peserta didik dapat dilihat dari tingginya prestasi belajar peserta didik, sedangkan tingginya tingkat prestasi belajar peserta didik dipengaruhi oleh minat dan motivasi belajar peserta didik itu sendiri.

Model pembelajaran adalah suatu rencana yang dapat kita gunakan untuk merancang pembelajaran tatap muka di dalam kelas atau dalam tutorial dan dalam membentuk material-material pembelajaran termasuk buku-buku, film, pita kaset, dan program media computer, dan kurikulum. Setiap model membimbing kita ketika kita merancang pembelajaran untuk membantu para pserta didik dalam mencapai tujuan. Menurut Kemp dalam Rusman (2010) mengemukakan bahwa: Strategi adalah suatu kegiatan pembelajaran yang harus dikerjakan pendidik dan peserta didik agar tujuan pembelajaran dapat dicapi secara efektif dan efisien. Sedangakn Dick dan Carey mengatakan bahwa strategi pembelajaran adalah suatu perangkat materi dan prosedur pembelajaran yang digunakan secara bersama-sama untuk menimbulkan hasil belajar pada peserta didik.

Sedangakan ciri-ciri model pembelajaran yang baik menurut Muhlis (2007) dalam versi KTS (Kurikulum Tingkat Satuan Pendidikan) adalah sebagai berikut: adanya keterlibatan inteltual-emosional peserta didik melalui kegiatan mengalami, menganalisis, dan pembentukan sikap. (a) Adanya keikutsertaan peserta didik secara aktif dan kreatif selama pelaksanaan mosel pembelajaran. (b) Guru bertindak sebagai fasilitator, koordinator, mediator, dan motovator dalam kegiatan belajar peserta didik. (c) Penggunaan berbagai metode, alat dan media pembelajaran.

Menurut Drost (1999) dalam Komara mengatakan bahwa proses pembelajaran dengan baik dan lancar jika terjalin hubungan manusiawi antar guru dan siswa, hubungan persaudaraan antar siswa, situasi saling membantu, disiplin kerja, tanggung jawab, mitra dalam pelajaran, menolong, kerja sama yang erat, berbagi pengalaman, dan diaolog reflektif antar pelajar. Hal tersebut juga sejalan dengan prinsip accelerated learning sebaimana yang dikemukakan Barkah (2002) dalam Komara bahwa landasan sosial dalam belajar mutlak harus ada karena adanya kerjasama akan membantu mempercepat belajar dan adanya persaingan akan memperlambat proses belajar.

Adapun macam-macam model pembelajaran intaraktif antara lain: (1) picture and ficture, (2) numbered headtogether, (3) student teams-achhievement divisions (STAD), (4) jigsaw/ model tim ahli, (5) mencari pasangan, (6) think pair and share, (7) debat, (8) role playing, (9) group investigation, (10) talking stick, (11) bertukar pasangan, (12) snowball throwing, (13) Komara Endang (2014: 24).

Pentingnya kearifan lokal dalam pendidikan kita secara luas adalah bagian dari upaya meningkatkan ketahanan nasional kita sebagai sebuah bangsa. Budaya nusantara yang plural dan dinamis merupakan sumber kearipan local yang tidak akan mati, karena semuanya adalah kenyataan hidup (living reality) yang tidak dapat dihindari (Syamsul, 2016: 3-5).

\section{METODE}

Pendekatan yang digunakan dalam penelitan ini yakni pendekatan kualitatif menggunakan pendekatan 
kualitatif karena data yang dikumpulkan bukan berupa angka melainkan data tersebut berasal dari observasi, wawancara dan dokumentasi. Penelitian kualitatif adalah penelitian yang datanya dinyatakan dalam bentuk verbal dan analisis tanpa menggunakan teknik statistik (E.G. Carmines dalam Sangadji, 2010: 26).

Penelitian ini akan dilaksanakan pada sekolah SMP Nusantara Makassar. Jenis dan sumber data yang digunakan dalam penelitin ini adalah sumber data primer dan sumber data sekunder. Untuk mengumpulkan data dalam penelitian ini digunakan teknik pengumpulan data observasi, wawancara, dan dokumentasi. Analis data dalam penelitian ini adalah data yang telah dikumpulkan, baik data primer maupun data sekunder dianalisis secara kualitatif dan selanjutnya dideskripsikan.

\section{HASIL DAN PEMBAHASAN}

Ada beberapa model pembelajaran yang lazim digunakan oleh guru IPS di SMP Nusantara Makassar diantaranya adalah model pembelajaran kooperatif tipe STAD, model pembelajaran Jigsaw, model pembelajaran problem bassed learnig, model pembelajaran mind mapping, dan model pembelajaran discovery learning, namun berdasarkan hasil penelitian menunjukkan bahwa implementasi model pembelajaran IPS yang berbasis kearifan lokal di SMP Nusantara adalah guru menerapkan dua model yaitu model mind mapping dan model discovery learning.

Pembelajaran yang berbasis kearifan lokal memberikan sebuah pengalaman psikologis kepada siswa selaku pengamat dan pelaksana kegiatan. Dampak psikologis dapat terlihat dari keberanian siswa dalam bertanya tentang ketidak tahuannya, mengajukan pendapat, persentasi di depan kelas, dan berkomunikasi dengan masyarakat. Pemanfaatan lingkungan maka kebutuhan siswa tentang perkembangan psikologisnya akan diperoleh. Karena lingkungan merupakan salah satu faktor yang mempengaruhi pembentukan dan perkembangan perilaku individu, baik lingkungan fisik maupun lingkungan psikologi sosial, termasuk didalamnya adalah belajar.

Berdasarkan hasil pengamatan di lapangan menunjukkan bahwa model pembelajaran mind mapping mampu membuat siswa lebih aktif dan termotivasi karena mereka dilatih dan diajari bagaimana memecahkan masalah yang terjadi misalanya dalam kehidupan sehari-hari dan siswa lebih tertantang untuk menggali nilai budaya yang ada disetiap daerah.

Guru IPS di SMP Nusantara Makassar dalam menggunakan model mind mapping hasilnya secara tidak langsung dapat merefleksikan otak siswa dan untuk kearifan lokalnya adalah menyeimbangkan ucapan siswa dan perbuatan dengan menanamkan kepribadian siswa. Dan hal ini juga tampak ketika siswa diberi tugas kelompok dengan membuat peta konsep tentang materi intekasi sosial dengan berbasis kearifan lokal yaitu siswa lebih aktif dan kreatif dalam mengerjakan tugas kelompok dan memaparkan hasilnya di depan teman-temannya artinya bahwa siswa sudah mampu mengembangkan dirinya dengan menyentuh aspek nilai sosial dan aspek keterampilan sosial akan tampak setelah siswa diberi tugas dalam memecahkan masalah-masalah sosial yang ada di lingkungan sekitar siswa melalui pembelajaran IPS dengan materi keragaman sosial dan budaya Indonesia. Guru dalam menyajikan materi melibatkan siswa secara aktif dengan membagi kelompok dengan membahas kebudayaan lokal setiap daerah sebagai 
pengembangan materi pelajaran yang disesuaikan dengan kompetensi dasar yang ingin dicapai dalam pembelajaran.

Model mind mapping adalah cara bagaimana siswa mencatat secara kreatif, efektif, dan mampu membuat peta konsep, dengan model pembelajaran ini siswa memperoleh informasi dengan cara menyimpan dalam otaknya sebagai pusat informasi sehingga siswa dengan mudah memahami materi yang diberikan oleh guru dan sikap siswa akan terlihat dalam proses belajar-mengajar.

Penerapan model pembelajaran discovery learning berbasis kearifan lokal pada mata pelajaran IPS di SMP Nusantara Makassar dapat diketahui berdasarkan hasil wawancara bahwa guru IPS memberikan stimulasi terlebih dahulu berupa rangsangan untuk berpikir dan menemukan solusi dari pemecahan masalah dengan memberikan tema adalah keragaman etnik penduduk Negara anggota ASEAN.

Pembelajaran IPS dengan model discovery learning ini mampu membentuk kepribadian siswa yang lebih mandiri dan bijak dalam mengatasi masalah sosial yang timbul dan secara kelompok bisa membentuk kepribadian yang harmonis antara sesama siswa, serta mempunyai kemampuan untuk mengambil keputusan sehingga siswa mampu mempertanggungjawabkan setiap keputusan yang diambilnya secara bersama sehingga model pembelajaran discovery learning menempatkan siswa sebagai pembelajar yang super aktif dalam membangun pengetahuan dan pemahamannya dalam melakukan eksprimen yang ada di lingkungan mereka masing-masing.

Dari hasil penelitaian dan pembahasan tersebut di atas, penelitian ini sejalan dengan teori Rahyono dalam Fajarini (2014: 2), bahwa kearifan local merupakan kecerdasan manusia yang dimiliki oleh kelompok etnis tertentu yang diperoleh melalui pengalaman masyarakat. Artinya, kearifan lokal adalah hasil dari masyarakat tertentu melalui pengalaman mereka dan belum tentu dialami oleh masyarakat yang lain. Nilai-nilai tersebut akan melekat sangat kuat pada masyarakat tertentu dan nilai itu sudah melalui perjalanan waktu yang panjang, sepanjang keberadaan masyarakat tersebut. Begitupula yang dialami siswa yang mampu menanamkan nilai-nilai budaya lokal melalui model pembelajaran yang diberikan oleh guru IPS di SMP Nusantara Makassar.

\section{PENUTUP}

Berdasarkan hasil penelitian dan pembahasan, adapun yang menjadi kesimpulan dalam penelitian ini adalah: implementasi Model pembelajaran IPS berbasis kearifan lokal di SMP Nusantara Makassar ada dua yaitu: guru menggunakan model pembelajaran mind mapping dan model pembelajaran discovery learning yang mampu meningkatakan motivasi belajar siswa dan mampu mengembangkan diri siswa dalam mengenali ragam budaya dengan melatih siswa meningkatkan potensi kemampuan dan keterampilan sosial siswa secara stimultan.

\section{DAFTAR PUSTAKA}

Fajarini, Ulfah. 2014. Peranan Kearifan Lokal Dalam Pendidikan Karakter. Jakarta: Universitas Islam Negeri (UIN) Syarif Hidayatullah Jakarta.

Komara, Endang. 2014. Belajar dan Pembelajaran Interaktif. Bandung: Refika Aditama.

Muhlis, Mansur. 2007. KTSP Pembelajaran Berbasis Kompetensi dan Konsektual. Malang: Bumi Aksara. 
Rusman. 20210. Model-model

Pembelajaran:

Mengembangkan

Profesionalisme Guru. Jakarta:

PT RajaGrafindo.

Sangadji, Etta Mamang \& Sopiah. 2010. Metodologi Penelitian-

pendekatan Praktis dalam Penelitian. Yogyakarta: ANDI

Syaiful Bahri Djamara dan Drs Aswan Zain. 2006. Strategi Belajar Mengajar, Jakarta: Rineka Cipta

Syamsul, Chaidir. 2016. Kearifan Lokal Bugis di Sulawesi. Makassar: UNM. 